\title{
Venturia species form sooty mold-like colonies on leaves of Salix: introducing Venturia fuliginosa sp. nov.
}

\author{
M. Shen, J.Q. Zhang and Y. Zhang* \\ Institute of Microbiology, P.O. Box 61, Beijing Forestry University, Beijing 100083, PR China \\ * Corresponding author. e-mail: Ying Zhang: yinghku@gmail.com.
}

M. Shen, J.Q. Zhang, Y. Zhang 2016 - Venturia species form sooty mold-like colonies on leaves of Salix: introducing Venturia fuliginosa sp. nov. Mycosphere 7 (9), 1292-1300, Doi 10.5943/mycosphere/7/9/4

\begin{abstract}
Collection of ascomycetes in the Lesser Khingan Mountains of China led to the discovery of two species of Venturia on Salix, one of which is described and illustrated as a new species $-V$. fuliginosa in this paper. Venturia fuliginosa forms a sooty mold-like phenotype on the leaf surface of the host, and differs from known species of Venturia in having fusiform, subcylindrical, sometimes obpyriform and mostly aseptate conidia. Phylogenetic inference based on analysis of combined LSU and ITS sequence data, indicate that the new species is closely related to a strain named $V$. chlorospora (CBS 470.61) isolated from Salix daphnoides in 1958 in France. The second species, Venturia catenospora, is reported for the first time in China.
\end{abstract}

Key words - follicolous fungi - phytopathogen - sooty molds - taxonomy

\section{Introduction}

Venturia Sacc. (Venturiaceae, Venturiales, Wijayawardene et al. 2014) is a cosmopolitan genus causing scab on leaves and fruits of woody plants, such as apple scab ( $V$. inaequalis (Cooke) G. Winter) and willow scab ( $V$. saliciperda Nüesch), while some other species of Venturia are saprobic on leaves (Nüesch 1960, Barr 1968). Several species of Venturia have been reported from Salix species, for example, Venturia chlorospora (Ces.) P. Karst. on Salicis vitellince L., Venturia saliciperda on Salix cordata Michx., Venturia austrogermanica Rehm on Salix reticulate L. and $V$. subcutanea Dearn. on Salix reticulate L. (Rabenhorst 1859, Rehm 1906, Dearness 1917, Nüesch 1960). Nüesch (1960) summarized the Venturia species on willows in Europe and reported five species including $V$. chlorospora, $V$. helvetica Nüesch, $V$. microspora Nüesch, $V$. saliciperda and $V$. subcutanea. Barr (1968) reported V. minuta M.E. Barr from Salix spp. in northeastern and northwestern North America, which was characterized by smaller ascospores. Sivanesan (1977) studied the type specimens of $V$. chlorospora, $V$. helvetica, $V$. minuta, $V$. saliciperda and $V$. subcutanea and transferred V. microspora to Niesslia as N. microspora (Speg.) Sivan. Fusicladium is the asexual morph of Venturia (Schubert et al. 2003, Crous et al. 2007a, b, Zhang et al. 2011, Rossman et al. 2015). In the monograph on Fusicladium sensu lato, four Fusicladium species had been reported on Salix species, including Fusicladium catenosporum (Butin) Ritschel \& U. Braun, F. saliciperdum (Allesch. \& Tubeuf) Lind, Fusicladium sp. 1 and Fusicladium sp. 2 (=Venturia chlorospora) (Schubert et al. 2003). As asexual and sexual morphs of the same genus must have one 
name, Rossman et al. (2015) recommended Venturia for protection over Fusicladium or Pollaccia, as the names in Venturia are more widely known. We follow this here.

During a survey of ascomycetes in the Lesser Khingan Mountain area, in the northern part of Heilongjiang Province in China, we collected two Venturia species on Salix. Based on morphological and molecular phylogenetic inferences, we introduce one as Venturia fuliginosa sp. nov., while $V$. catenospora is a new record for China.

\section{Material \& methods}

\section{Sample collection, specimen examination and fungal isolation}

Samples were collected from leaves of Salix species in August 2014 in the Hailun Expressway Service Area and Fenglin Nature Reserve of the Heilongjiang Province in China. They were first dried with absorbent paper in a specimen press. For examination under an Olympus SZ 61 dissecting microscope leaves were incubated in a moist chamber. Microscopic observations of conidiophores, conidiogenous cells and conidia were carried out from material mounted in water. Photomicrographs were taken on a Nikon Eclipse E600 microscope fitted with a Nikon Digital Sight DS FI1 camera and processed with NIS-Elements F 3.2 software.

Single conidia were isolated on $2 \%$ malt extract agar (MEA; Crous 2002, Gams et al. 2007). Colonies were subcultured onto fresh MEA, potato-dextrose agar (PDA) and incubated at $26-28{ }^{\circ} \mathrm{C}$ under continuous near-ultraviolet light to promote sporulation. Fungal isolates and herbarium specimens were deposited at the Beijing Forestry University (BJFU) and duplicates in the Mycological Herbarium of the Institute of Microbiology, Chinese Academy of Sciences (HMAS).

\section{DNA extraction and PCR amplification}

DNA was extracted from mycelium grown on MEA plates with the CTAB plant genome DNA fast extraction kit (Aidlab Biotechnologies Co., Ltd, Beijing, China). The 28S nuc rDNA (LSU) was amplified and sequenced with primers LR0R and LR5 (Vilgalys \& Hester 1990), and the nuc rDNA internal transcribed spacer (ITS) with primers ITS-1 and ITS-4 (White et al. 1990).

\section{Sequence alignment and phylogenetic analysis}

Sequences generated were analyzed with other sequences obtained from GenBank. ABLAST query was performed to find possible sister groups of the newly sequenced taxon, and only closely related sister groups are included in the phylogenetic analysis (Table 1). A multiple alignment was conducted in MEGA 5 (Tamura et al. 2011) and analyses were performed in PAUP V. 4.0b10 (Swofford 2002) and MrBayes v. 3.1.2 (Ronquist \& Huelsenbeck 2003). Prior to phylogenetic analysis, ambiguous sequences at the start and the end were deleted and gaps were manually adjusted to optimize alignment. A combined LSU and ITS dataset was analysed. Maximum parsimony analyses were conducted using heuristic searches as implemented in PAUP, with the default options method. Analyses were done under different parameters of maximum parsimony criteria as outlined in Zhang et al. (2008). Clade stability was assessed in a bootstrap analysis with 1000 replicates, random sequence additions with maxtrees set to 1000 and other default parameters as implemented in PAUP. For the MrBayes analysis, the best-fit model of nucleotide evolution $(\mathrm{GTR}+\mathrm{I}+\mathrm{G})$ was selected by Akaike information criterion (AIC; Posada \& Buckley 2004) in MrModeltest 2.3. The metropolis-coupled Markov Chain Monte Carlo (MCMCMC) approach was used to calculate posterior probabilities. A preliminary Bayesian inference (BI) analysis using MrBayes software revealed that the Markov Chain Monte Carlo (MCMC) showed constant average standard deviation of split frequencies below 0.01 after less than 1,266,000 generations. A conservative burn-in of 12,600 dendrograms was chosen and a full analysis of 5,000,000 generations was carried out with sampling every 100 generations. Trees were viewed in TREEVIEW (Page 1996). The nucleotide sequences reported in this paper were deposited in GenBank. Trees and alignments were deposited in TreeBase with study ID S20293. 


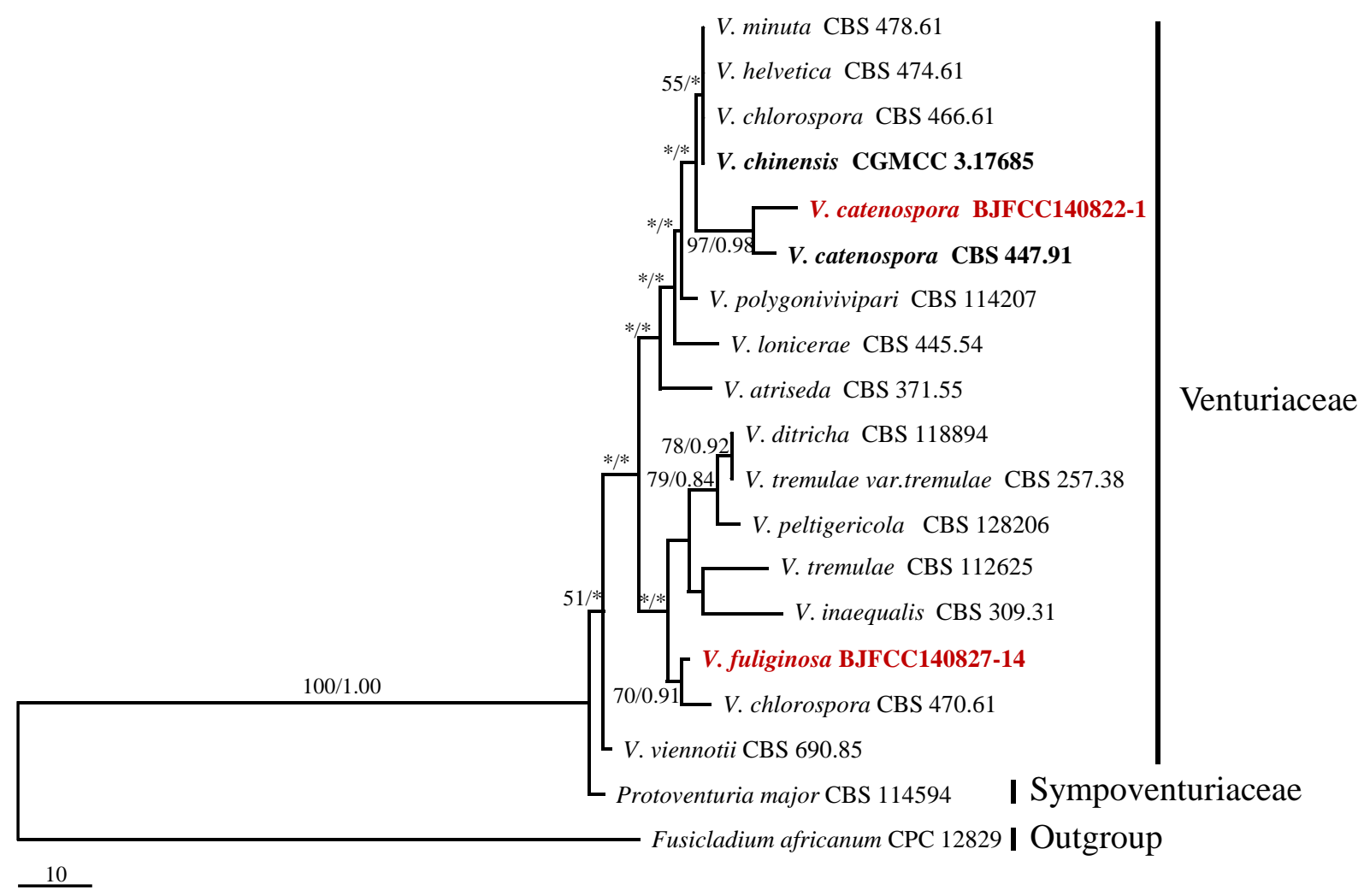

Fig. 1 Maximum parsimony tree generated from sequence analysis of the combined ITS and LSU sequence dataset. The outgroup taxon is Fusicladium africanum (CPC 12829). Maximum parsimony bootstrap support values above $50 \%$ and Bayesian posterior probabilities support above $80 \%$ are given above or under the branches (MP/PP). Ex-type sequences are printed in bold face and new sequences in red bold face.

Table 1. Species and sequences database accession numbers used in this study (newly generated sequences are indicated in bold).

\begin{tabular}{llll}
\hline Species & Source & of & \multicolumn{2}{l}{ GenBank accession no. } \\
\cline { 3 - 4 } & sequences & 28S rDNA & ITS \\
\hline Fusicladium africanum & CPC 12829 & EU035424 & EU035424 \\
Protoventuria major & CBS 114594 & JQ036233 & \\
Venturia atriseda & CBS 371.55 & EU035448 & EU035448 \\
Venturia catenospora & BJFCC140822-1 & KU220966 & KU220964 \\
Venturia catenospora & CBS 447.91 & EU035427 & EU035427 \\
Venturia chinensis & CGMCC 3.17685 & KP689595 & KP689596 \\
Venturia chlorospora & CBS 466.61 & EU035453 & EU035453 \\
Venturia ditricha & CBS 118894 & EU035456 & EU035456 \\
Venturia chlorospora & CBS 470.61 & EU035454 & EU035454 \\
Venturia fuliginosa & BJFCC140827-14 & KU220967 & KU220965 \\
Venturia helvetica & CBS 474.61 & EU035458 & EU035458 \\
Venturia inaequalis & CBS 309.31 & EU035437 & EU035437 \\
Venturia lonicerae & CBS 445.54 & EU035461 & EU035461 \\
Venturia minuta & CBS 478.61 & EU035464 & EU035464 \\
Venturia peltigericola & CBS 128206 & HQ599579 & HQ599579 \\
Venturia polygoni-vivipari & CBS 114207 & EU035466 & EU035466 \\
Venturia tremulae & CBS 112625 & EU035438 & EU035438 \\
Venturia tremulae var. tremulae & CBS 257.38 & EU035475 & EU035475 \\
Venturia viennotii & CBS 690.85 & EU035476 & EU035476 \\
\hline
\end{tabular}




\section{Results}

\section{Taxonomy}

Venturia catenospora (Butin) Rossman \& Crous, in Rossman et al., IMA Fungus 6: 5202015. Facesoffungi number: FoF 02755, Fig. 2

Leaf spots occurring on both sides of the leaves, scattered, subcircular or irregular, 4-15 mm wide, dark olivaceous-brown, margin dark brown to blackish, often causing distortions at the leaf margin, leaves deformed. Colonies occurring on both sides of the leaves, dense, oblong or circular, dark olivaceous-brown, sometimes confluent. Mycelium immersed, subcuticular, forming colourless, circular hyphal plates. Sexual morph: Undetermined. Asexual morph: Asexual morph: Hyphomycetous. Conidiophores reduced to conidiogenous cells. Conidiogenous cells determinate or rarely percurrent, 11-23 $\times 5-8 \mu \mathrm{m}, 0-1$-septate, medium olivaceous-brown, with up to two annellations, loci truncate or slightly convex, $(2-) 3-4(-5) \mu \mathrm{m}$ wide, not to slightly thickened, not darkened. Conidia 13-27.5 $\times 5-8 \mu \mathrm{m}$, catenate, in unbranched or rarely branched chains, ellipsoid, limoniform or fusiform, straight to sometimes slightly curved, 0-1(-2)-septate, pale to olivaceousbrown, smooth-walled, wall somewhat thickened, truncate at the apex and base, hila 2-3.5 $\mu \mathrm{m}$ wide, unthickened to occasionally very slightly thickened, slightly darkened.

Cultural characteristics - Colonies $43 \mathrm{~mm}$ after 1 month at $25{ }^{\circ} \mathrm{C}$ in the dark, erumpent, spreading, with abundant aerial mycelium and feathery to smooth margins; surface grey-olivaceous, reverse dark olivaceous.

Known distribution - China, Germany, Latvia.

Specimen examined - CHINA, Heilongjiang Province, Hailun City, Hailun Expressway Service Area, $47^{\circ} 28^{\prime} \mathrm{N}, 126^{\circ} 53^{\prime} \mathrm{E}$, ca. $219 \mathrm{~m}$ asl, on leaves of Salix sp. (Salicaceae), 22 August 2014, leg. Y. Zhang \& Y.P. Zhou, HMAS 247006 (living culture, BJFCC140822-1).

Notes: Pollaccia catenospora Butin was described by Butin (1992, type strain: CBS 447.91) from Europe, and subsequently transferred to Venturia (as V. catenospora) by Rossman et al. (2015). Butin (1992) and Ritschel (2001) described the conidiogenous cells of $V$. catenospora as having annellations. Two conidiogenous loci without annellations, however, were observed in this study, which agrees with the description by Schubert et al. (2003). The type strain (CBS 447.91) and the strain isolated in this study of $V$. catenospora form a conspecific clade on the dendrogram (Fig. 1, with ITS similarity of $98.7 \%$ and LSU similarity of $99.6 \%$ ), which possibly means annellations or conidiogenous loci has little significance at species level classification.

Venturia fuliginosa Y. Zhang ter \& J.Q. Zhang, sp. nov.

MycoBank 815331; Facesoffungi number: FoF 02756, Figs 3-4

Holotype - HMAS 247007.

Etymology - In reference to the "sooty" mold-like colonies formed on host leaves.

Pathogen on living leaves and petioles, forming sooty mold-like diffuse and flattened colonies. Mycelium superficial, spreading, dense, brown; hyphae septate, unbranched or rarely branched, with oblong to cylindrical cells. Sexual morph: Undetermined. Asexual morph: Hyphomycetous. Conidiophores reduced to conidiogenous cells. Conidiogenous cells branched or unbranched, 2-3 $\mu \mathrm{m}$ wide, septate, medium brown, roughened, with somewhat thickened walls. Conidia 9-17 × 4.5-7 $\mu \mathrm{m}$, solitary, ellipsoid to cylindrical, straight, sometimes slightly curved, 0-2septae, pale to medium brown, somewhat roughened, with slightly thickened walls, obconically truncate at the base, hila truncate, $2-3.5 \mu \mathrm{m}$ wide, slightly thickened, not darkened.

Cultural characteristics - Colonies $14 \mathrm{~mm}$ after 1 month at $25{ }^{\circ} \mathrm{C}$ in the dark on MEA, erumpent, spreading, with abundant aerial mycelium and feathery to smooth margins, surface greyolivaceous, reverse dark olivaceous. On MEA, hyphae smooth, pale greenish, yellow or medium brown, branched, 2-5 $\mu \mathrm{m}$ wide, with typically darkened septa, frequently forming coils. Conidiophores laterally arising from hyphae or reduced to conidiogenous cells, erect, straight to somewhat flexuous, sometimes geniculate, branched or unbranched, 3-7 $\mu \mathrm{m}$ wide, septate or aseptate, pale brown or medium brown, smooth, walls somewhat thickened, sometimes only as short 
lateral conical prolongation of hyphae, occasionally irregular in shape. Conidiogenous cells integrated, terminal, sometimes geniculate, 6-30 × 3-7 $\mu \mathrm{m}$, with sympodial proliferation; loci 1-3 denticle-like, broadly truncate, 2-2.5 $\mu \mathrm{m}$ wide, unthickened, somewhat refractive or darkened. Conidia 14-23 $\times$ 4-7 $\mu \mathrm{m}$, catenate, formed in unbranched or loosely branched chains, straight to sometimes curved, sometimes irregularly swollen, fusiform, subcylindrical, sometimes obpyriform, $0-1(-2)$-septate, pale brown, smooth, with slightly thickened walls, slightly attenuated towards apex and base; hila broadly truncate, $1-2(-3) \mu \mathrm{m}$ wide, unthickened or only slightly thickened, somewhat darkened-refractive; conidia often germinating when arranged in chains.
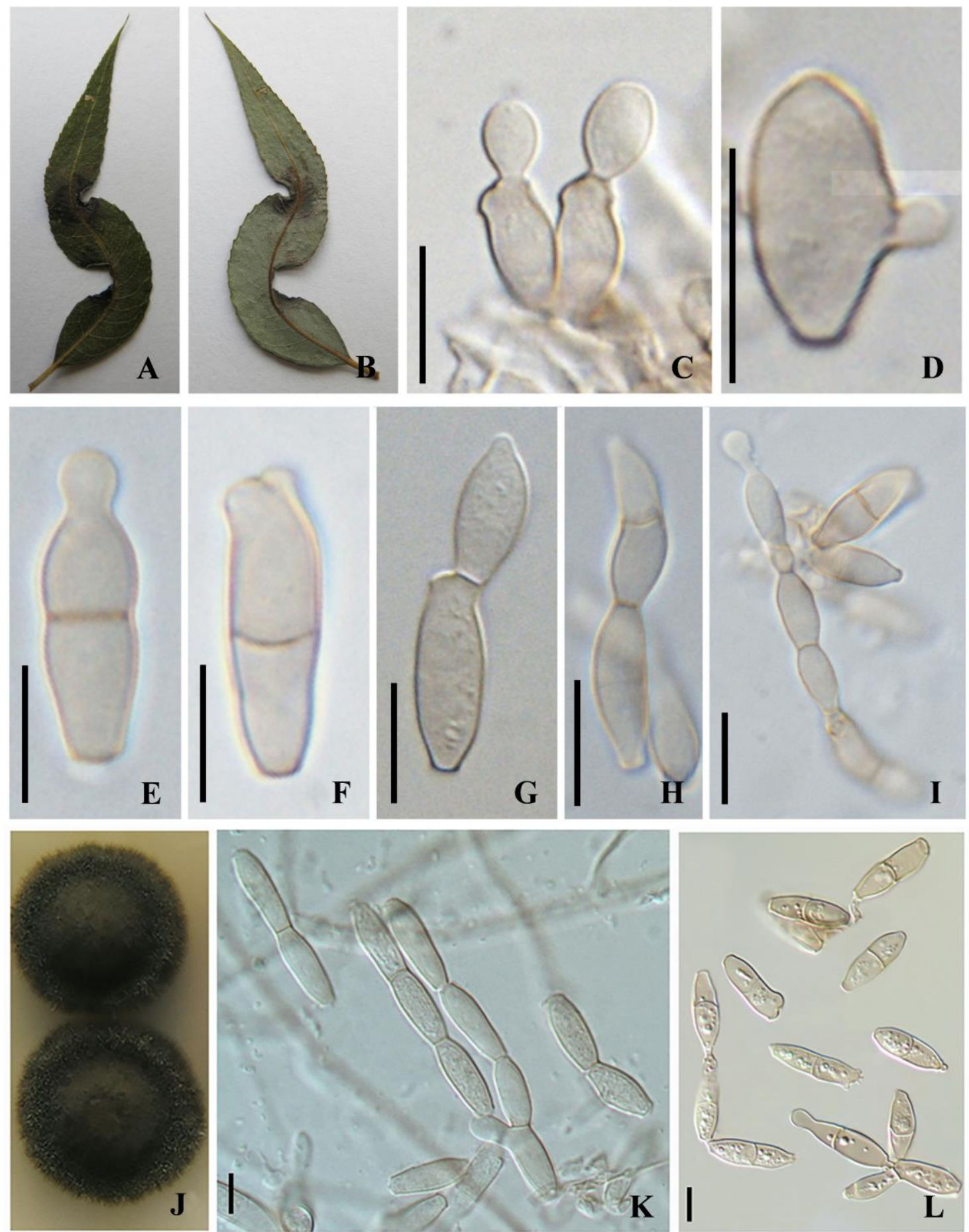

Fig. 2 Venturia catenospora (A-I from herbarium specimen HMAS 247006, J-L from BJFCC140822-1). A, B Leaves infected by $V$. catenospora. C, E-G, K, L Conidiogenous cells and conidia. D Germinating conidia. H, I Conidial chains. J. Colony growing on MEA. Scale bars: $\mathrm{C}-\mathrm{L}=10 \mu \mathrm{m}$. 

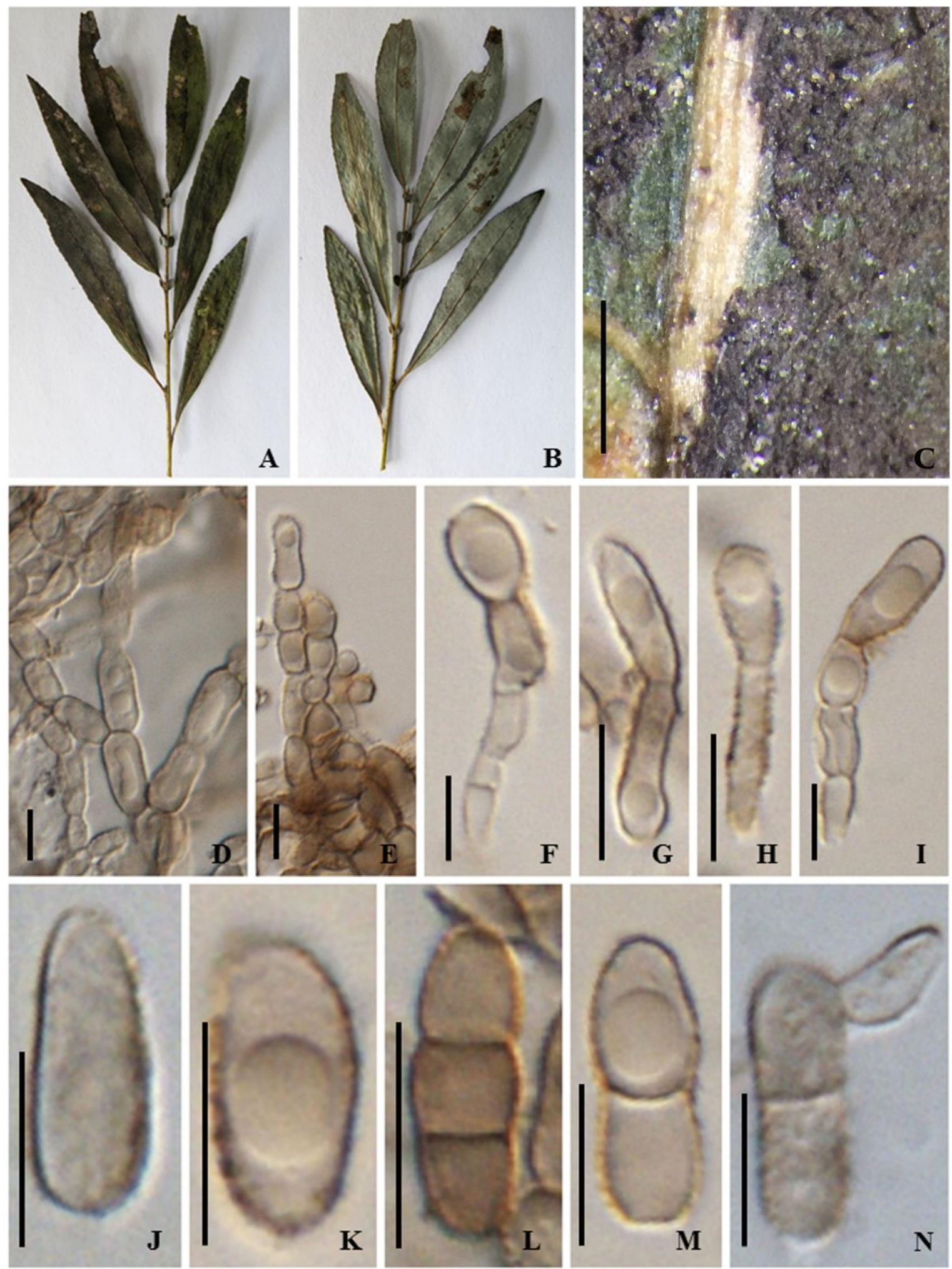

Fig. 3 Venturia fuliginosa (HMAS 247007, holotype herbarium). A-C Sooty mold-like colonies on the host. D, E Conidial chains. F-I Conidiophores with conidiogenous cells. J-M Conidia. N Germinating conidia. Scale bars: $\mathrm{C}-\mathrm{N}=10 \mu \mathrm{m}$.

Holotype - CHINA. Heilongjiang Province, Yichun City, Fenglin Nature Reserve, 48 $07{ }^{\prime} \mathrm{N}$, $129^{\circ} 11^{\prime} \mathrm{E}$, ca. $423 \mathrm{~m}$ asl, on leaves of Salix capitata (Salix sect. Subalbae Koidzumi), 27 August 2014, leg. Y. Zhang \& Y.P. Zhou, HMAS 247007 (ex-type strain, BJFCC140827-14).

Notes: Numerous globes fruiting bodies were produced on the surface of the sooty mold-like colonies after the dried specimen kept for 6 months, while no sexual structures (i.e. asci) were observed inside. Thus no sexual stage was determined for this species yet. 

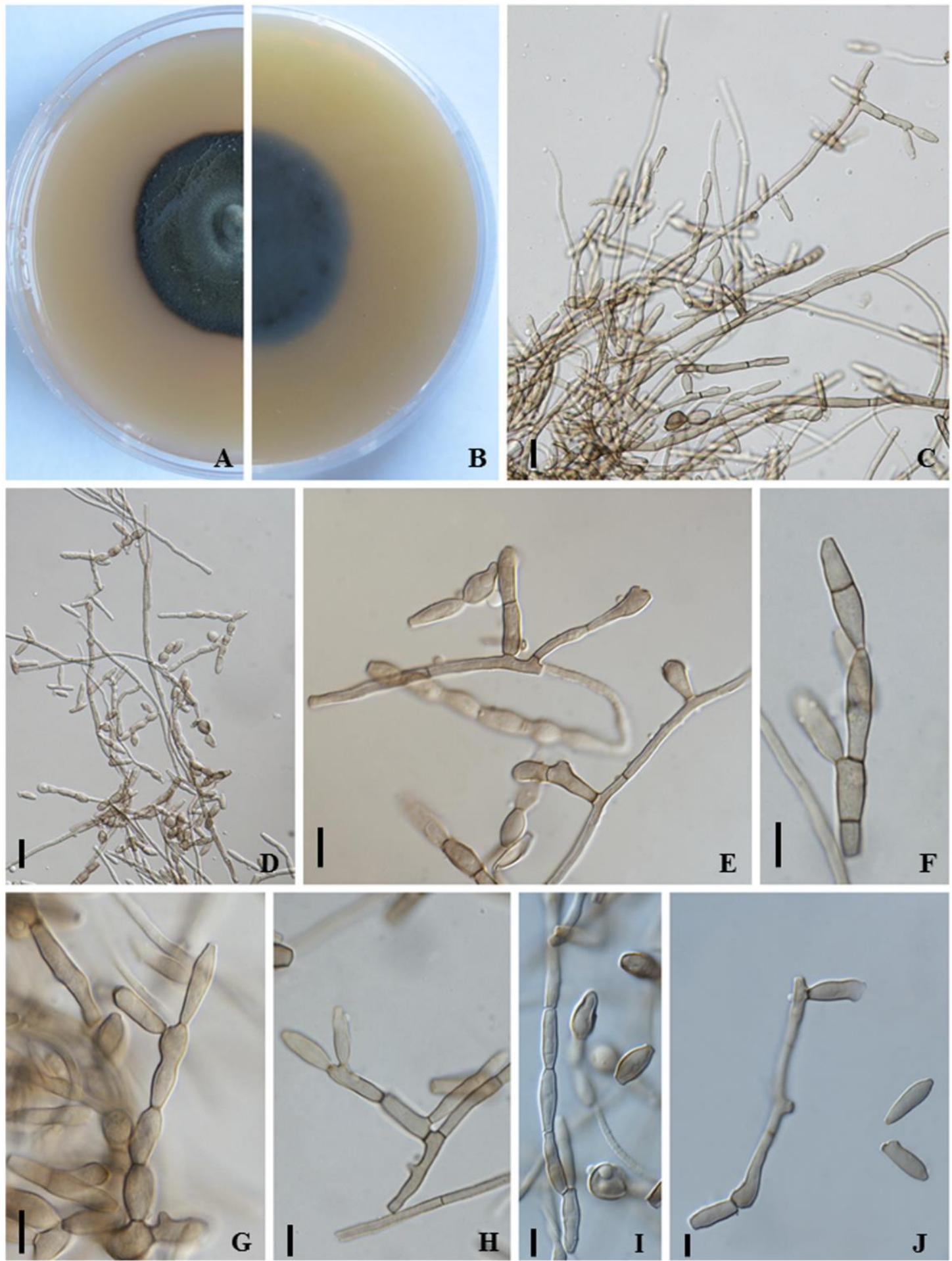

Fig. 4 Venturia fuliginosa (BJFCC140827-14, ex-type strain). A, B Colony growing on MEA. C, D Conidial chains and septate hyphae. E-J Conidiogenous cells and conidial chains. Scale bars: C, D = $20 \mu \mathrm{m}$; E-J $=10 \mu \mathrm{m}$.

Only the asexual morphs of Venturia fuliginosa was observed in this study. Venturia fuliginosa forms a robust clade with CBS 470.61 (Fig. 1, with ITS similarity of $99 \%$ and 28 S similarity of $100 \%$ ). Both CBS 466.61 and CBS 470.61 were collected and named as $V$. chlorospora by Nüesch from Switzerland and France on Salix spp respectively, while they were distinct in molecular phylogeny (Fig. 1, with ITS similarity of $97 \%$ and $28 \mathrm{~S}$ similarity of 99\%). The asexual morph of $V$. chlorospora formed in culture, and was described by Nüesch (1960) as conidia produced in unbranched chains (Sivanesan 1977: 55), which differs from the unbranched or loosely branched chains of $V$. fuliginosa. In addition, the sooty mould-like asexual colonies of $V$. fuliginosa on the host surface, differs from other reported species of Venturia (or Fusicladium). CBS 470.61 proved to be 
sterile in culture, and did not produce a Fusicladium morph to enable comparison with the Chinese strain. In particular, ITS sequence data has proven insufficient to distinguish species of Venturia (Zhang et al. 2016).

\section{Discussion}

Colonies of Venturia fuliginosa form a sooty mold-like layer on leaf surface of Salix capitata, and have superficial, densely spreading mycelium, causing a diffuse, flattened, plumose subicula with sooty mould-like appearance. Seven fungal families, viz. Antennulariellaceae, Capnodiaceae, Chaetothyriaceae, Coccodiniaceae, Euantennariaceae, Metacapnodiaceae and Trichomeriaceae have been reported as forming sooty molds on host leaves (Chomnunti et al. 2011, 2014). This is the first report of sooty mold-like colonies caused by a venturiacous taxon.

Venturia chlorospora (CBS 466.61), V. helvetica and $V$. minuta were phylogenetically indistinguishable in this study (Fig. 1, with similarities of ITS and LSU being 100\%). All the isolates of these three species used here were collected from Salix species in Swiserland by Nüesch, while their conspecific status needed to be confirmed by further study. The ex-type isolate of $V$. catenospora (CBS 447.91) was used here, which was obtained from willow (Salix triandra) in Germany (Butin 1992). Morphologically, our new collection of $V$. catenospora (HMAS 247006) is similar with the original description of $V$. catenospora (Butin 1992), and the LSU and ITS sequence comparisons support their conspecific status (see comments above). Venturia catenospora is reported for the first time in China.

\section{Acknowledgements}

This study was supported by National Science and Technology Foundation Project (2014FY210400), National Natural Science Foundation of China (General Program, 31370063) and NSFC Projects of International Cooperation and Exchanges (31461143028). Prof. Dr. Pedro W. Crous was acknowledged for his incubating and checking the asexual morph of CBS 470.61 as well as improving this manuscript.

\section{References}

Barr ME 1968 - The Venturiaceae in North America. Canadian Journal of Botany 46, 799-864.

Butin H 1992 - Pollaccia catenospora sp. nov. associated with leaf spots of willow. Mycological Research 96, 658-660.

Chomnunti P, Hongsanan S, Aguirre-Hudson B, Tian Q et al. 2014 - The sooty moulds. Fungal Diversity 66, 1-36.

Chomnunti P, Schoch CL, Aguirre-Hudson B, Ko Ko TW et al. 2011 - Capnodiaceae. Fungal Diversity 51, 103-134.

Crous PW 2002 - Taxonomy and pathology of Cylindrocladium (Calonectria) and allied genera. APS Press, Minnesota, St. Paul, USA.

Crous PW, Mohammed C, Glen M, Verkley GJM, Groenewald JZ 2007a - Eucalyptus microfungi known from culture. 3. Eucasphaeria and Sympoventuria genera nova, and new species of Furcaspora, Harknessia, Heteroconium and Phacidiella. Fungal Diversity 25, 19-36.

Crous PW, Schubert K, Braun U, de Hoog GS et al. 2007b - Opportunistic, human-pathogenic species in the Herpotrichiellaceae are phenotypically similar to saprobic or phytopathogenic species in the Venturiaceae. Studies in Mycology 58, 185-217.

Dearness J 1917 - New or noteworthy North American fungi. Mycologia 9, 345-364.

Gams W, Verkley GJM, Crous PW 2007 - CBS Course of Mycology, 5th ed. Centraalbureau voor Schimmelcultures, Utrecht.

Nüesch J 1960 - Beitrag zur Kenntnis der weidenbewohnenden Venturiaceae. Phytopathologische Zeitschrift 39, 329-360.

Posada D, Buckley TR 2004 - Model selection and model averaging in phylogenetics: advantages of Akaike information criterion and Bayesian approaches over likelihood ratio tests. Systematic 
Biology 53, 793-808.

Rabenhorst 1859 - Fungi Europaei Exsiccati, ed. nov., ser. 2, no. 48.

Rehm H 1906 - Beiträge zur Ascomyceten Flora der deutschen Alpen und Voralpen. Österreichische Botanische Zeitschrift 56, 291-348.

Ritschel A 2001 - Taxonomische Revision der Gattungen Pollaccia und Spilocaea (Hyphomycetes, Venturia-Anamorphen), Diplom-Arbeit, Martin-Luther-Universität. Halle, 1-88.

Ronquist F, Huelsenbeck JP 2003 - MrBayes 3: Bayesian phylogenetic inference under mixed models. Bioinformatics 19, 1572-1574.

Rossman AY, Crous PW, Hyde KD, Hawksworth DL et al. 2015 - Recommended names for pleomorphic genera in Dothideomycetes. IMA Fungus 6, 507-523.

Schubert K, Ritschel A, Braun U 2003 - A monograph of Fusicladium s. lat. (Hyphomycetes). Schlechtendalia 9, 1-132.

Sivanesan A 1977 - The taxonomy and pathology of Venturia species. J. Cramer, Vaduz, Liechtenstein. pp. 138 .

Swofford DL 2002 - PAUP*. Phylogenetic Analysis Using Parsimony (*and other methods). Version 4.0b10. Sinauer Associates, Sunderland, Massachusetts.

Tamura K, Peterson D, Peterson N, Stecher G et al. 2011 - MEGA5: molecular evolutionary genetics analysis using maximum likelihood, evolutionary distance, and maximum parsimony methods. Molecular Biology and Evolution 28, 2731-2739.

Vilgalys R, Hester M 1990 - Rapid genetic identification and mapping of enzymatically amplified ribosomal DNA from several Cryptococcus species. Journal of Bacteriology 172, 4238- 4246.

White TJ, Bruns T, Lee S, Taylor J 1990 - Amplification and direct sequencing of fungal ribosomal RNA genes for phylogenetics. In: Innis MA, Gelfand DH, Sninsky JJ, White TJ (eds), PCR Protocols: a guide to methods and applications. Academic Press, New York, pp. 315-322.

Wijayawardene NN, Crous PW, Kirk PM, Hawksworth DL et al. 2014 - Naming and outline of Dothideomycetes-2014 including proposals for the protection or suppression of generic names. Fungal Diversity 69, 1-55.

Zhang JQ, Dou ZP, Zhou YP, He W et al. 2016 - Venturia chinensis sp. nov., a new venturialean ascomycete from Khingan Mountains. Saudi Journal of Biological Sciences 23, 592-597.

Zhang Y, Crous P, Schoch C, Bahkali A et al. 2011 - A molecular, morphological and ecological reappraisal of Venturiales-a new order of Dothideomycetes. Fungal Diversity 51, 249-277.

Zhang Y, Jeewon R, Fournier J, Hyde KD 2008 - Multi-gene phylogeny and morphotaxonomy of Amniculicola lignicola: a novel freshwater fungus from France and its relationships to the Pleosporales. Mycological Research 112, 1186-1194. 